\title{
Wiestaw Hudek
}

Akademia Muzyczna im. K. Szymanowskiego w Katowicach

\section{„Pieśń moją śpiewam królowi” (Ps 45, 2). \\ O kategorii muzycznego piękna w celebracji liturgicznej}

\section{Biblijno-teologiczne przestanki obecności piękna w muzyce liturgicznej}

Niech pierwszym słowem będzie słowo natchnione. Słowo śpiewane, słowo psalmu, Psalmu 45, czyli Weselnej pieśni dla Pomazańca Bożego w kilku różnych szatach literackich.

Najnowszy przekład z języków oryginalnych podaje wersję poniższą:

45, 2 Moje serce wezbrało pięknym słowem, poświęcam me dzieło królowi. Język mój jak pióro biegłego pisarza.

45, 3 Ty jesteś najpiękniejszy pośród ludzi, wdzięk rozlał się na twych wargach: dlatego Bóg zawsze cię błogosławi ${ }^{1}$.

Jan Kochanowski:

45, 2 Serce mi każe śpiewać panu swemu, / A sercu język posłuszny pełnemu

Odbiera słowa i nowy rym dzieje; / Ledwie tak prędko pisarz pismo leje. 45, 3 Żaden, o królu, żaden twej urody / Nie dojdzie między ludzkimi narody,

Żaden wdzięczności pięknej twarzy twojej / Hojnie-ć użyczył Pan Bóg łaski swojej².

1 Pismo Święte Starego i Nowego Testamentu, opracował Zespół Biblistów Polskich z inicjatywy Towarzystwa Świętego Pawła, Częstochowa 2009, s. 1186.

2 Psatterz Dawidów w przektadzie Jana Kochanowskiego, red. B. Banaszek, Sandomierz 2000, s. 90 . 


\section{Czesław Miłosz:}

45, 2 Wezbrało moje serce słowem wdzięcznym, mówię moją pieśń królowi, język mój jak rylec biegłego pisarza

45, 3 Urodziwy jesteś nad synów ludzkich, łaskawość na wargach twoich, dlatego pobłogosławił ciebie Bóg na wieki³

Jest już w tej miłosnej pieśni, w jej dwóch zaledwie wersetach zawarta intencja, która porusza myśli i moje pragnienia. Więcej w niej (tej intencji) żaru i zachwytu niż rozstrzygnięć niepodlegających dyskusji. Jestem bowiem więcej uczestnikiem i koncelebransem aniżeli zimnym obserwatorem, fotografem czy rejestratorem. Moją intencją jest, by pięknym słowem opisać to Piękno, które dało początek wszystkiemu. Niech mi będzie wolno do tych trzech tłumaczeń dorzucić jeszcze czwarte z Liturgii godzin. Psalm 45 pojawia się w tam w Nieszporach, w poniedziałek II tygodnia, a także w Wielki Poniedziałek. To, co różnicuje, wiąże się $\mathrm{z}$ antyfoną. W pierwszym przypadku tę antyfonę stanowi wers trzeci Psalmu 45: „Najpiękniejszy jesteś spośród synów ludzkich, wdzięk rozlał się na twoich wargach"; w drugim (w Wielki Poniedziałek) antyfona „pochodzi” z Izajasza (Iz 53, 2): „Nie miał on wdzięku ani blasku, aby na Niego poprzeć, ani wyglądu, by się nam podobal"5.

To zestawienie nie jest przypadkowe. Rozpoczynając refleksję nad kategorią muzycznego piękna w liturgii, celowo odwołuję się do największego ze współczesnych teologów. Papież Benedykt XVI, konstruując teologię estetyki, wchodzi niejako w sam środek liturgii, i posługując się paradoksem, odkrywa rdzeń tego, co jest istotą piękna w ujęciu chrześcijańskim. Z doskonałej monografii ks. profesora Jerzego Szymika przepisuję jej (istoty piękna) interpretację:

W paradoksalnym zestawieniu dwóch antyfon w postaci Chrystusa - Najpiękniejszym, a bez wyglądu i blasku, pełnym wdzięku i pozbawionym wdzięku zarazem, tkwi jakaś gę̧bsza prawda o życiu i tajemnicy piękna, jakiś zarys nowego kształtu estetyki. [...] To miłość godzi się na oszpecenie, w którym to akcie miłości mieści się cała synteza piękna i prawdy: wolność, absolutna bezinteresowność, niezgłębiona wielkość daru z siebie,

3 Księga psalmów, tłumaczył z hebrajskiego Czesław Miłosz, Paryż 1981, s. 131.

4 Liturgia Godzin, t. 3, Poznań 1987, s. 705.

5 Liturgia Godzin, t. 2, Poznań 1984, s. 337. 
zgoda na rezygnację z piękna, z jego autonomii, podporządkowanie go dobru drugiego - miłości właśnie. Radykalizm proegzystencji ${ }^{6}$.

Taki właśnie, głęboko papieski rys estetyki chrześcijańskiej proponuję przyjąć na początku rozważań o kategorii muzycznego piękna w celebracji liturgicznej. Jakiej głębi i świeżości nabiera wobec tych treści Augustiańskie Cantare amantis est („Śpiewanie jest potrzebą kochającego”), dopowiedzmy: potrzebą kochającego serca, kochającego człowieka. Czy w innym miejscu [w Wyznaniach]: „Prawdziwą piękność dostrzega wewnętrzne oko duszy, a nie oko fizyczne” (VI, 16)ำ. Jak ważne są precyzyjne rozróżnienia kardynała Ratzingera związane z innym psalmem (Ps 47), zawarte w doskonałym zbiorze Nowa pieśń dla Pana. Wiara w Chrystusa a liturgia dzisiaj. Stwierdza kardynał - przyszły papież Benedykt XVI:

Punktem wyjścia niech będzie przypomnienie, że Biblia ma swój własny śpiewnik: Psałterz, który nie tylko zrodził się z praktyki liturgicznego śpiewu i muzykowania, ale zawiera również istotne elementy teorii muzyki powstałej w wierze i dla wiary ${ }^{8}$.

I interpretując znaczenie określenia „Śpiewajcie Bogu pięknie”, dodaje:

Spotkanie z Bogiem stanowi wyzwanie dla najwyższych zdolności człowieka. Wielkości Boga człowiek odpowiada tylko wtedy, gdy w miarę swych możliwości wkłada również w swoją odpowiedź całą godność piękna, wzniosłość rzeczywistej sztuki

I niebywale dosadna i trafna diagnoza:

Na wstępie wyszliśmy do schizofrenii współczesnej twórczości artystycznej wahającej się między nurtem pop a elitarnym estetyzmem. Tym samy zaznaczone są już dwie linie graniczne, przy których przekroczeniu muzyka wyrzeka się kultury wiary i tym samym przestaje być muzyką z ducha słowa Bożego i dla słowa Bożego ${ }^{10}$.

${ }^{6}$ J. Szymik, Theologia benedicta, t. 1, Katowice 2010, s. 101.

7 św. Augustyn, Wyznania, tłum. T. Kubiak, Kraków 1994, s. 135.

8 J. Ratzinger, Nowa pieśń dla Pana. Wiara w Chrystusa a liturgia dzisiaj, Kraków 1999, s. 154.

9 J. Ratzinger, Nowa pieśń dla Pana, dz. cyt., s. 163.

${ }^{10}$ J. Ratzinger, Nowa pieśń dla Pana, dz. cyt., s. 168. 
Powróćmy do istoty sprawy, piękna ściśle związanego z miłością:

Święto liturgiczne rządzone jest prawem nadmiaru, bo rządzi się prawem miłości. Miłość nie pyta o minimum, ale pragnie się dawać w nadmiarze. Bóg w swojej nieskończonej miłości udziela człowiekowi łask w nadmiarze i daje siebie bez końca. Wspólnota wierzących jest więc zobowiązana do możliwie wspaniałomyślnego, wielkodusznego kształtowania chwalby Bożej i dziękczynienia, to znaczy do proponowania Bogu tego, co posiada najcenniejszego i najpiękniejszego. Muzyka ze swej natury jest szczególnie przeznaczona do tego, aby ów dar uwydatnić. Nie narusza ona niczego w samej istocie obrzędów i w treści słów, pozornie też niczego nie dodaje, a jednak wymaga większego nakładu środków wyrazu. Wymaga np. czasu, zaangażowania, przygotowania, dyscypliny i to nie tylko przed, ale i w czasie akcji liturgicznej. Jeśli w świecie cywilizacji technicznej brakuje dzisiaj odpowiednich dyspozycji u człowieka do przeżywania bogato rozwiniętej obrzędowości, jeśli w związku z tym woła się o maksymalne uproszczenie liturgii, to czy nie wyraża się w ten sposób skąpstwa w oddawaniu czci Bogu? Czy więc nie trzeba zdobyć się na wysiłek wychowywania wiernych do oddawania Bogu tego, co najlepsze i najpiękniejsze? Czy przez milczące przyzwolenie na takie tendencje nie prowadzi się do małoduszności, obojętności i prostactwa, a przez to do podeptania godności liturgii? ${ }^{11}$.

Aby ukazać, jak wiele muzyka ma do zaoferowania celebracji liturgicznej, a zwłaszcza jej pięknu, warto dotknąć poszczególnych jej rodzajów, gatunków, a wreszcie konkretnych utworów. W nich bowiem można odczytać inkarnację Piękna i piękno Wcielenia...

\section{Piękno poszczególnych rodzajów muzyki liturgicznej}

\section{Muzyka wokalna}

W obrębie wokalnej muzyki liturgicznej niepodważalnie najwyższą pozycję, ze względów historycznych, estetycznych i teologicznych zajmuje chorał gregoriański. W dokumentach Kościoła nazywany jest „własnym śpiewem liturgii

${ }^{11}$ I. Pawlak, Muzyka liturgiczna po Soborze Watykańskim II w świetle dokumentów Kościota, Lublin 2001, s. 79. 
rzymskiej”12 i dlatego „w liturgii powinien on zajmować pierwsze miejsce wśród innych równorzędnych rodzajów śpiewu”. W refleksji muzykologicznej można znaleźć opinie szczególnie afirmatywne:

W jednogłosowych formach śpiewu chorałowego - hymnach i sekwencjach, antyfonach i responsoriach, częściach mszalnych - sacrum przejawia się przez piękno. Jest to piękno nadprzyrodzone. Chora - czyli to, co istotnie muzyczne w liturgii, aktualizowane $\mathrm{w}$ melodii i rytmie - ukazuje nam pełną harmonię, niemal tożsamość „sakralnego” i „estetycznego". [...] Chorał gregoriański jest objawieniem tego, co święte, poprzez czysty śpiew: poprzez ruch i kierunek melodyczny toku; poprzez sposób śpiewania - artykulację, akcenty metryczne, frazowanie; poprzez wznoszenie się i opadanie śpiewanych dźwięków; poprzez pauzy, zawieszenia, oddechy; poprzez płynność i wyrazistość recytatywności, falistość i strzelistość melizmatyki, poprzez uduchowioną intonację i barwę głosu. To emanowanie sakralności ze śpiewu chorałowego odczuwamy nawet wtedy, gdy nie dociera do nas sama treść słów tekstu: świadczy to o szczególnej duchowej sile „żywiołu” muzycznego natchnionego świętością ${ }^{13}$.

Warto wspomnieć przy tej okazji o zasadach, które zwerbalizował święty Jan Paweł II:

Odnośnie do liturgicznych utworów muzycznych uznaję za swoje „ogólne prawo”, które św. Pius X ujął w następujące słowa: „kompozycja jakaś dla kościoła przeznaczona jest tym świętsza i tym bardziej liturgiczna, im bardziej w przebiegu swym, w natchnieniu i smaku zbliża się do melodii gregoriańskiej, tym zaś mniej jest godna świątyni, im bardziej z tym najwyższym wzorem staje się niezgodna”. Nie chodzi oczywiście o tworzenie kopii śpiewu gregoriańskiego, lecz raczej nasycenie nowych kompozycji tym samym duchem, który ożywiał i stopniowo kształtował ten śpiew ${ }^{14}$.

${ }^{12}$ Sobór Watykański II, Konstytucja o Świętej Liturgii, 116 [dalej: KL], [w:] A. Filaber, Prawodawstwo muzyki kościelnej, Warszawa 2008, s. 40.

${ }^{13}$ B. Pociej, Sacrum w muzyce dzisiaj-problem estetyki, Lublin 1982, s. 4, cyt. za: J. Waloszek, Teologia muzyki. Wspótczesna myśl teologiczna o muzyce, Opole 1997, s. 277.

${ }^{14}$ Jan Paweł II, List „Mosso dal vivo desiderio” ogtoszony $w$ setna rocznice Motu proprio "Tra le Sollecitudini” o muzyce sakralnej, „Ethos” nr 73-74 (2006), s. 19. 
Ze śpiewem gregoriańskim wiążą się inne rodzaje i gatunki muzyki wokalnej: monodia liturgiczna $\mathrm{w}$ językach narodowych (m.in. w języku polskim), dawne i nowe pieśni, polifonia a cappella dawna i współczesna. Dość powiedzieć, że w każdym z tych rodzajów muzyki liturgicznej można się zetknąć z pięknem emanującym na różne sposoby:

1) przez prostotę melodyczną pieśni kościelnych, których teksty niejednokrotnie stają się mniejszymi czy większymi traktatami teologicznymi ${ }^{15}$;

2) poprzez bogactwo harmoniczne wielogłosowości; od napełnionej konsonansami i motoryczną meliką polifonii palestrinowskiej poprzez często homofoniczne malowanie tekstu u „cecylianistów” aż po pełną niepokoju i dźwiękowego nasycenia muzykę romantyczną i współczesną ${ }^{16}$;

3) poprzez liczbę funkcji składających się na „symfonicznośc” liturgii (muzyki wokalnej) objawiająca się inaczej w śpiewach solowych celebransa, psałterzysty, kantora, a zupełnie inaczej w utworach przeznaczonych do wykonania przez zespół wokalny: scholę, chór czy całe zgromadzenie liturgiczne ${ }^{17}$.

Warto, odnosząc się do każdej z tych potencjalnych emanacji piękna wokalnej muzyki liturgicznej, zwrócić uwagę na niektóre możliwości, a także zagrożenia, jeszcze raz zaznaczając, iż nie mają one charakteru zakończonych rozstrzygnięć, a raczej prób naświetlenia problematyki.

Ad 1. We współczesnej praktyce liturgicznej prawie cała muzyka obecna w przestrzeni celebracji została sprowadzona do pieśni ludowej, często w ograniczonej ilości pozycji repertuarowych, oraz stosowana bez zachowania prawi-

${ }^{15}$ Przykładowo pieśń Upadnij na kolana jako Kontrapunkt IX - Pieśń kościelna prosta i piękna: T. Jasiński, Jana Pawła II myśl o sztuce i dwanaście muzycznych kontrapunktów, Lublin 2006, s. 70 .

${ }^{16} \mathrm{O}$ kategorii muzycznego piękna, sakralności oraz konkretnych możliwościach dotyczących stosowania repertuaru polifonicznego a capella zob. np. B. Pociej, Stadia muzycznej duchowości. Trzy wyktady, Katowice 2009, s. 58-59; S. Dąbek, Twórczość mszalna kompozytorów polskich XX wieku (1900-1995), Warszawa 1996; S. Dąbek, Wokót problematyki pojęciowej oraz pewnych idei, w kontekście dziejów wielogtosowej muzyki w Polsce (do Vaticanum II), [w:] "Thesaursus Musicae Sacrae summa cura servetur et foveatur". Historia i wspótczesność muzyki liturgicznej w Polsce 100 lat od wydania Motu proprio papieża Piusa X, red. S. Dąbek, I. Pawlak, Lublin 2004, s. 106-117; A. Zając, Teologiczne aspekty uczestnictwa chóru w liturgii, „Liturgia Sacra” 7 (2001) nr 1 (17), s. 95-108.

${ }^{17} \mathrm{~Np}$. Z. Wit, Zaangażowanie świeckich w postugi muzyczne w liturgii, [w:] Muzyka liturgiczna w Kościele Katowickim 1925-2005, red. W. Hudek, Katowice 2005, s. 27-43; A. Reginek, Miejsce i znaczenie kościelnych zespotów śpiewaczych w liturgii po Soborze Watykańskim II, [w:] Muzyka liturgiczna w Kościele Katowickim 1925-2005, dz. cyt., s. 45-52, I. Pawlak, Muzyka liturgiczna po Soborze Watykańskim II..., dz. cyt., s. 223-261, 274-283. 
deł zawartych w dokumentach ${ }^{18}$. Kanon takich śpiewów nie jest wcale ubogi. Przykładowo w Śpiewniku archidiecezji katowickiej umieszczono prawie 800 pieśni i śpiewów liturgicznych. Obejmują one m.in. - by ograniczyć się tylko do śpiewów okresowych - 24 pieśni adwentowe, 57 kolęd, 53 śpiewy wielkopostne; 46 śpiewów paschalnych. Jeśli porównać to zestawienie z repertuarem, który stosowany jest $\mathrm{w}$ parafiach, znajdziemy pośrednio odpowiedź na pytanie o inkarnację piękna Bożego orędzia w muzyczną przestrzeń liturgii. W tej kwestii (inkarnowania piękna poprzez muzykę wokalna) bardzo ważne jest umiejętne odczytywanie przesłania słowa Bożego i innych tekstów liturgicznych oraz ich uzgadnianie z wykonywanymi pieśniami ${ }^{19}$.

Ad 2. Należałoby poprzestać na rudymentarnym stwierdzeniu, iż nie należy się bać wielkiej literatury sakralnej polifonii, zarówno dawnej, jak i współczesnej. Nieufność, a często wrogość w stosunku do niej, wynikają ze współczesnych pokus pragmatyzmu i funkcjonalności oraz źle pojętego aktywnego uczestnictwa. Nie do zastąpienia są tutaj praktyczne rozważania kardynała Ratzingera, które mogą pomóc zarówno samym muzykom kościelnym, jak i duszpasterzom w stosowaniu właściwego repertuaru i umiejętnym łączeniu nova et veter ${ }^{20}$. Podobnie jak w przypadku monodii liturgicznej zastosowanie takiego, a nie innego repertuaru powinno wiązać się z kontemplacją ducha liturgii (por. Joseph Ratzinger), a nie postawą utylitaryzmu czy doraźnych „efektów duszpasterskich”, które wiążą się z hołdowaniem zasadom tzw. kultury masowej ${ }^{21}$. Dzieła polifoniczne dawnych

${ }^{18}$ Warto przypomnieć najistotniejsze wytyczne prawodawstwa. Dokumenty Kościoła określają warunki, które powinna spełniać muzyka liturgiczna: (1) musi być uznana przez Kościół za swoją modlitwę; (2) zawarta jest w księgach zatwierdzonych przez Stolicę Apostolską; (3) teksty uznane za „święte” mają być wykonywane wg melodii zawartych w tych księgach (śpiewy celebransa i ministrów); (4) inne teksty (wiernych, scholi, chóru etc.) powinny być wykonane wg melodii, które Kościół uzna za swoje; (5) w doborze repertuaru powinna być zachowana pewna hierarchia, w której pierwsze miejsce należy się chorałowi gregoriańskiemu. Por. I. Pawlak, Muzyka liturgiczna po Soborze Watykańskim II..., dz. cyt., s. 59.

${ }^{19}$ Szeroko na ten temat: W. Hudek, Zasady doboru śpiewów mszalnych, [w:] Sacrum i profanum $w$ muzyce wokalnej i instrumentalnej, red. M. Pietrzykowska, G. Rubin, Bydgoszcz 2010, s. $172-188$.

${ }^{20}$ J. Ratzinger, Nowa pieśń dla Pana, dz. cyt., s. 217-227.

${ }^{21}$ „Trzeba pamiętać, że kultura masowa nastawiona jest na ilość, produkcję i sukces. Proces tworzenia takiej muzyki podobny jest do produkcji przemysłowej: specjaliści od rytmu, melodii, instrumentacji, harmoniki, czyli poszczególnych elementów dzieła muzycznego, jak na taśmie produkcyjnej bezdusznie dodają swój element wg ustalonych zasad. Taki „produkt" i sam proces jego powstawania dalekie są od kultury Ewangelii i świętych czynności. Ewangelia bowiem pragnie wyzwolenia dla człowieka z dyktatury pieniądza, manipulacji, miernoty i pragnie go przywieść do dyscypliny prawdy, której za pomocą muzyki pop 
i współczesnych mistrzów są sprzymierzeńcami piękna i modlitwy, które otwierają człowieka na Tajemnicę Boga Żywego...

Ad 3. Wielkie możliwości kształtowania muzycznego piękna zależą w dużym stopniu od samych wykonawców wokalnej muzyki liturgicznej. Istotną rolę w pogłębianiu świadomości spełniają różne działania formacyjne. Od zwykłych i systematycznych, do których należy zaliczyć: regularne próby scholi czy chóru, profesjonalne wykształcenie muzyczne celebransów (biskupa, prezbitera i diakona) oraz ministrów (kantora i psałterzysty), do wyjątkowych, przygodnych, ale mających na celu „przebudzenie” muzyczne wspólnoty, jak: odbywające się w określonych odstępach czasowych dni (np. raz w roku) i kongresy (np. co pięć lat) muzyki liturgicznej, koncerty, festiwale, spotkania i seminaria przybliżające szerokiemu gronu odbiorców znaczenie muzycznego piękna i muzycznych posług w liturgii. Wówczas muzyka i cała liturgia stają się „wyspą, gdzie żyje wiara w Boga, trwa wewnętrzna prostota chrześcijaństwa i stąd [tu: z muzyki i liturgii, przyp. W. H.] może ono promieniować w świat”"22. Wówczas liturgia poprzez wokalną emanację muzycznego piękna może stać się prawdziwą „pocieszycielką"23.

\section{Muzyka instrumentalna}

Liturgiczna muzyka instrumentalna w Kościele rzymskokatolickim kojarzy się jednoznacznie z dźwiękiem organów i asocjacja taka jest jak najbardziej uprawniona, chociażby ze względu na liczne wypowiedzi papieży, soborów czy poszczególnych episkopatów zawarte w dokumentach. Warto przytoczyć kilka:

Pierwszeństwo przed wszelkimi innymi instrumentami w świętych obrzędach mają organy, tony ich bowiem wybornie harmonizują ze świętymi pieniami i obrzędami, dodając im prawdziwej wspaniałości i przepychu; wzniosłością zaś swoją i słodyczą wzruszają serca wiernych, napełniając je jakoby niebiańską radością i mocno pociągają ku Bogu i rzeczom wyższym (Pius XII, enc. Musicae sacrae disciplina, 29) ${ }^{24}$.

właśnie się unika. To medium zabija przesłanie, niszczy orędzie. Następuje wówczas banalizacja wiary, czyli zaprzeczenie kultury”. I. Pawlak, Muzyka liturgiczna po Soborze Watykańskim II..., dz. cyt., s. 222.

22 Świattość świata: Papież, Kościót i znaki czasu. Benedykt XVI w rozmowie z Peterem Seewaldem, przekł. P. Napiwodzki, Kraków 2011, s. 183.

${ }^{23}$ J. S. Pasierb, Stowo Boże między ludźmi, Katowice 2010, s. 175.

${ }^{24}$ Cyt. za: A. Filaber, Prawodawstwo muzyki kościelnej, dz. cyt., s. 30. 
W Kościele łacińskim organy piszczałkowe należy mieć w wielkim poszanowaniu jako tradycyjny instrument muzyczny, którego brzmienie potęguje wzniosłość kościelnych obrzędów, a umysły wiernych porywa ku Bogu i rzeczywistości nadziemskiej (KL 120) 25 .

Organy powinny znajdować się we wszystkich kościołach w Polsce. Tzw. organy elektronowe dopuszcza się do użytku jako instrument tymczasowy. Natomiast tam, gdzie ze względu na brak miejsca nie da się zbudować organów piszczałkowych, można je instalować zamiast fisharmonium (Instrukcja Episkopatu Polski o muzyce liturgicznej po Soborze Watykańskim II, 28) ${ }^{26}$.

Sprawa muzyki organowej, zarówno solowej, jak i stanowiącej akompaniament liturgiczny w polskiej rzeczywistości (ale zdaje się również szerzej, w całej Europie, z różnym natężeniem) jest sprawą kluczową w procesie inkarnacji muzycznego piękna w samej liturgii, a także w procesie przygotowywania i wychowywania poszczególnych wspólnot do spotkania z Bogiem poprzez piękno ${ }^{27}$. Ze względu na totalny upadek kultury muzycznej, ignorancję w kwestiach muzycznego wychowania społeczeństwa, wszechobecną (w mediach, na ulicy, w sklepach itd.) kulturę masową, a co za tym idzie również muzykę z terenu „popłuczyn cywilizacyjnych”, jedyna możliwość spotkania się ze sztuką prawdziwą umiejscowiona jest właśnie w przestrzeni liturgicznej celebracji.

Zdaje się, że to, co przez wieki kształtowało gust muzyczny, smak estetycznych wyborów, a także poziom muzycznej wyobraźni, zależało w dużej mierze od organisty, który w swojej społeczności bywał tzw. dyrektorem muzycznym. Stąd sprawą priorytetową pozostają kwestie pośrednio i bezpośrednio łączące się z kategorią piękna. Należą do nich m.in.: uregulowanie statusu materialnego i pozycji społecznej organisty we wspólnocie parafialnej, odpowiednie jego wykształcenie, a następnie jego permanentna formacja (muzyczna, liturgiczna, duchowa), prowadzenie systematycznych ćwiczeń wokalnych z celebransami,

${ }^{25}$ Cyt. za: A. Filaber, Prawodawstwo muzyki kościelnej, dz. cyt., s. 40.

${ }^{26}$ Cyt. za: A. Filaber, Prawodawstwo muzyki kościelnej, dz. cyt., s. 64-65.

27 W. Delimat, Ksztatcenie muzyków kościelnych $w$ Polsce i jego wptyw na repertuar muzyki sakralnej, [w:] Muzyka w stużbie liturgii, red. R. Tyrała, Kraków 2005, s. 97-106; G. Piekarz, Organista - zawód czy powotanie?, [w:] Cantate Domino Canticum novum. Księga pamiątkowa dedykowana Księdzu Kazimierzowi Pasionkowi, red. S. Garnczarski, Tarnów 2004, s. 293-307; W. Hudek, Organista i jego postuga - refleksje liturgiczno-muzyczne, [w:] W. Hudek, Stowa dźwiękiem malowane, Lublin 2005, s. 55-62. 
innymi wykonawcami muzyki liturgicznej oraz zgromadzeniem liturgicznym, wykonywanie literatury organowej $\mathrm{w}$ ramach celebracji ${ }^{28}$ oraz $\mathrm{w}$ przestrzeni koncertów, a także organizowanie życia muzycznego w parafii poprzez zakładanie zespołów śpiewaczych, instrumentalnych, rozbudzanie zainteresowania muzyką itd. Możliwości, ale i profity wynikające z takiej działalności są nie do przecenienia, $\mathrm{z}$ uwagi na to, że praca ta wiąże się w nierozerwalny sposób ze światem wartości ${ }^{29}$.

W kwestii innej niż organowa muzyki instrumentalnej przytoczmy klasyczny tekst z encykliki Piusa XII:

Oprócz organów dopuszczalne są inne jeszcze instrumenty muzyczne, mogące przyczynić się skutecznie do osiągnięcia wzniosłego celu, jaki ma przed sobą muzyka sakralna. W ich użyciu wszakże nie może być nic światowego, nic hałaśliwego czy krzykliwego, gdyż to uchybiałoby powadze miejsca i świętości obrzędu liturgicznego (Pius XII, Musicae sacrae disciplina, 30$)^{30}$.

Jakkolwiek dzisiaj dyskusja dotycząca obecności innych instrumentów w celebracji liturgicznej nie toczy się, generalnie rzecz ujmując, na poziomie nakazów i zakazów, to wciąż liturgiczna muzyka instrumentalna pozostaje przestrzenią niezagospodarowaną ${ }^{31}$. Warto jednak odnotować pozytywny fakt, iż w roku 2009 (9-11 września) Stowarzyszenie Polskich Muzyków Kościelnych zorganizowało w Pelplinie spotkanie poświęcone tematowi muzyki instrumentalnej. Poszczególni prelegenci poruszali kwestie historyczne $e^{32}$, prawodawcze ${ }^{33}$ oraz praktyczne

${ }^{28}$ G. Klauza, Muzyka organowa w codziennej liturgii Kościota, „Ethos” nr 73-74 (2006), s. 87-99.

${ }^{29}$ B. F. Dunikowska, Akt twórczy organisty w ramach liturgii Kościoła rzymskokatolickiego w kontekście wartości, [w:] Wartości w muzyce, t. 4, Muzyka w środowisku spotecznym, red. J. Uchyła-Zroski, Katowice 2012, s. 205-218.

${ }^{30}$ Cyt. za: A. Filaber, Prawodawstwo muzyki kościelnej, dz. cyt., s. 30.

${ }^{31}$ I. Pawlak, Muzyka liturgiczna po Soborze Watykańskim II..., dz. cyt., s. 188-208.

${ }^{32}$ T. Rakowski, Muzyka instrumentalna $w$ tradycji katedry pelplińskiej, „Biuletyn Stowarzyszenia Polskich Muzyków Kościelnych” 5 (2010), s. 44-48; W. Hudek, Muzyka instrumentalna $w$ tradycji sanktuarium $w$ Piekarach Śląskich, „Biuletyn Stowarzyszenia Polskich Muzyków Kościelnych” 5 (2010), s. 49-60; J. M. Gładysz, Muzyka instrumentalna w tradycji sanktuarium w Tuchowie, „Biuletyn Stowarzyszenia Polskich Muzyków Kościelnych” 5 (2010), s. 61-65.

${ }^{33}$ I. Pawlak, Muzyka instrumentalna w świetle dokumentów Kościoła, „Biuletyn Stowarzyszenia Polskich Muzyków Kościelnych” 5 (2010), s. 17-25. 
możliwości ich zastosowania w liturgii ${ }^{34}$. Ten materiał badawczy może stanowić podstawę do rozwinięcia zarówno samego tematu w aspekcie teoretycznym, jak i konkretnych działań zmierzających w kierunku upowszechnienia już istniejących oraz powstawania nowych utworów czysto instrumentalnych napisanych specjalnie na potrzeby liturgii. Jest zamierzeniem organizatorów Festiwalu Twórczości Religijnej Fide et Amore ogłoszenie corocznego konkursu kompozytorskiego na taką właśnie twórczość powiązaną z konkretnym okresem roku liturgicznego ${ }^{35}$.

\section{Muzyka wokalno-instrumentalna}

Często powtarza się stereotypową opinię o tym rodzaju muzyki, stwierdzając ze smutkiem, iż Kościół katolicki w swojej tradycji nie posiada wielkich form muzyki wokalno-instrumentalnej, którymi mógłby się poszczycić tak samo, jak protestanci wspaniałym dziedzictwem muzyki Jana Sebastiana Bacha. Wydaje się jednak, iż współczesne badania muzykologiczne, a także żywe zainteresowanie muzyką dawną zadają kłam takiemu twierdzeniu, przywracając wiele zapomnianych dzieł praktyce wykonawczej. Warto wspomnieć o wspaniałych nieszporach Antonia Vivaldiego (zrekonstruowanych przez Rinaldo Alessandriniego), błyskotliwych ordinariach Mozarta czy Haydna, ale również o chętnie wykonywanych utworach liturgicznych kompozytorów polskich: Mikołaja Zieleńskiego, Marcina Mielczewskiego, Bartłomieja Pękiela, Grzegorza Gerwazego Gorczyckiego, Józefa Elsnera, Stanisława Moniuszki. Nie sposób wymienić wszystkich, którzy tworzyli wielkie kompozycje mszalne w wieku XX; byli to m.in.: Feliks Nowowiejski, Witold Maliszewski, ks. Wacław Gieburowski, Tadeusz Szeligowski, Jan Adam Maklakiewicz, ks. Leon Świerczek, Roman Palester, Józef Świder, Wojciech Kilar oraz reprezentanci młodszego pokolenia: Miłosz Bembinow, Paweł Łukaszewski, ks. Wojciech Kałamarz (CM), Weronika Ratusińska czy Alicja Gronau ${ }^{36}$.

Warto również zaznaczyć, iż pojawiają się symptomy oznaczające większe zrozumienie dla repertuaru wokalno-instrumentalnego przywracanego do przestrzeni liturgicznej, czy to w ramach działającego na Jasnej Górze Stowarzyszenia

${ }^{34}$ E. Malik, Udziat orkiestry dętej w liturgii na przyktadzie dziatalności mtodzieżowej orkiestry dętej „Camerata” z parafii św. Rocha w Starych Budkowicach, „Biuletyn Stowarzyszenia Polskich Muzyków Kościelnych” 5 (2010), s. 31-40.

35 W roku 2014 w ramach VIII edycji Fide et Amore zostanie ogłoszony konkurs kompozytorski na utwór instrumentalny (na organy solo, skrzypce z organami lub obój z organami) przeznaczony do wykonania w ramach obrzędu uwielbienia w okresie Narodzenia Pańskiego.

36 Por. S. Dąbek, Wspótczesna muzyka religijna. Uwarunkowania i aspekt duchowy, „Ethos” nr 73-74 (2006), s. 76-86. 
Musica Claromontana (mającego na koncie w ramach cyklu Jasnogórska muzyka dawna nagranie ponad 50 CD), czy istniejącego od 2002 roku „Projektu Mozart" będącego bezprecedensowym przedsięwzięciem kulturalnym zakładającym wykonanie wszystkich oratoryjnych dzieł Wolfganga Amadeusza Mozarta w ciągu 18 lat. Wszystkie koncerty odbywają się w wersji historycznej. Muzyka wykonywana przez chór, solistów i orkiestrę grającą na instrumentach z epoki Mozarta spleciona jest z liturgią sprawowaną w języku łacińskim, połączoną z prezentacją multimedialną. Zakończenie osiemnastoletniego cyklu jest zaplanowane na rok 2020. Stowarzyszenie zamierza wykonać wtedy słynne Requiem - ostatnią mszę Mozarta - w największych europejskich stolicach. Ośmioletnia działalność stowarzyszenia zaowocowała ponad 70 koncertami w 20 miastach Polski, a także w Łucku i we Lwowie na Ukrainie, gromadząc w sumie ok. 50 tysięcy słuchaczy. Tak duże zainteresowanie „Projektem Mozart” wynika z oryginalnej formuły koncertów stowarzyszenia oraz z ich wysokiej jakości artystycznej ${ }^{37}$.

Niech zachętą do wprowadzania w życie, zachętą do inkarnawania piękna muzyki wokalnej, instrumentalnej oraz wokalno-instrumentalnej będą słowa wieloletniego ceremoniarza papieskich celebracji, abpa Piero Mariniego:

Piękno liturgii wymaga zawsze jakiegoś wyrzeczenia z naszej strony: wyrzeczenia się banału, fantazji i kaprysu. Ponadto trzeba jej dać odpowiedni czas i przestrzeń, jakiej potrzebuje. Nie należy się śpieszyć. Bardziej Bogu niż naszej inicjatywie należy zostawić wolność mówienia i dotarcia do nas za pomocą słowa, modlitwy, gestów, muzyki, śpiewu, światła, kadzidła i zapachu. Liturgia, podobnie jak kompozycja muzyczna, potrzebuje przestrzeni, czasu i ciszy, oderwania się od nas samych, aby mogły nam powiedzieć o Bogu słowa, gesty i znaki ${ }^{38}$.

\section{Inkarnacje piękna muzycznego w praktyce liturgicznej}

By nie poprzestać na wytyczeniu ogólnych zasad, poprzez które można „dotknąć” tajemnicy muzycznego piękna w kontekście liturgii, proponuję trzy spotkania z konkretną muzyką w konkretnym czasie i przestrzeni. Każda z tych propozycji opatrzona zostanie stosownym wprowadzaniem aktualizującym przesłanie zawarte w liturgii (obrzędzie liturgicznym, okresie roku kościelnego, tajemnicy dnia) przez prezentowany przykład muzyczny.

37 V Festiwal Twórczości Religijnej Fide et Amore. Przewodnik festiwalowy, red. W. Hudek, Katowice 2011, s. 26.

${ }^{38}$ P. Marini, Liturgia i piękno, tłum. W. Dzierża, Pelplin 2007, s. 131. 


\section{Śpiew na uwielbienie}

22 listopada przypada wspomnienie św. Cecylii, dziewicy i męczennicy, patronki muzyki kościelnej. Na liturgię, która będzie celebrowana z udziałem chóru i organisty, proponuję, aby w obrzędzie uwielbienia wykonano opracowanie Psalmu 95 (96), którego treść warto przytoczyć w całości ${ }^{39}$. Arvo Pärt ${ }^{40}$, urodzony

${ }^{39}$ Śpiewajcie Panu pieśń nową, śpiewajcie Panu, wszystkie krainy!

Śpiewajcie Panu, błogosławcie Jego imię, z dnia na dzień głoście Jego zbawienie!

Rozgłaszajcie Jego chwałę wśród narodów, Jego cuda - wśród wszystkich ludów!

Bo wielki jest Pan i godzien wielkiej chwały, wzbudza On większy lęk niż wszyscy bogowie.

Bo wszyscy bogowie pogan to ułuda, a Pan uczynił niebiosa.

Przed Nim kroczą majestat i piękno, potęga i jasność w Jego przybytku.

Oddajcie Panu, rodziny narodów, oddajcie Panu chwałę i [uznajcie] potęgę; oddajcie Panu chwałę Jego imienia!

Nieście ofiary i wchodźcie do Jego przedsieni, oddajcie pokłon odziani w święte szaty!

Zadrżyj, cała ziemio, przed Jego obliczem!

Mówcie wśród pogan: Pan jest królem.

Umocnił świat, by się nie poruszył: ze słusznością wymierza ludom sprawiedliwość.

Niech się cieszy niebo i ziemia raduje; niech szumi morze i to, co je napełnia; niech się weselą pola i wszystko, co jest na nich, niech się także radują wszystkie drzewa leśne przed obliczem Pana, bo nadchodzi, bo nadchodzi, aby sądzić ziemię.

On będzie sądził świat sprawiedliwie, z wiernością swą - narody.

Por. Pismo Święte Starego i Nowego Testamentu, s. 1259.

${ }^{40}$ Arvo Pärt (ur. 11 września 1935 w Paide) - estoński kompozytor muzyki chóralnej i instrumentalnej. Studiował w konserwatorium w Tallinnie pod kierunkiem Heino Ellera. Początkowo komponował w stylu neoklasycystycznym, następnie eksperymentował z awangardą. Po okresie przerwy stworzył oryginalny styl „tintinnabuli” (łac. dzwonek), którego nazwa pochodzi od podobieństwa muzyki do grających dzwonków. To podejście kompozytor tłumaczy następująco: „Odkryłem, że wystarczy mi, gdy pięknie zagrana jest pojedyncza nuta. Ona sama, albo cichy rytm, albo moment ciszy - przynoszą mi wytchnienie”. Twórczość Arvo Pärta nie reprezentuje (jak niektórzy uważają błędnie) nurtu zwanego minimalizmem. Nawiązuje natomiast do hezychii (z gr. uciszenie), praktyk medytacyjno-ascetycznych mnichów ze Świętej Góry Atos. Twórczość ta oparta jest na redukcjonizmie mającym na celu stworzenie atmosfery kontemplacji właściwej dla tekstów, którymi kompozytor się posługuje, czyli najczęściej należącymi do religii i liturgii rzymskokatolickiej. Jak sam kompozytor mówi, muzyka ta ma więcej wspólnego z wielowiekową tradycją chorału gregoriańskiego i polifonii renesansowej niż z twórczością minimalistów amerykańskich, takich jak Steve Reich. Jednocześnie w warstwie estetycznej bliska jest założeniom koncepcji minimalistycznych, obecnych w nurcie XX-wiecznego nurtu „minimalizmu duchowego” (Sofija Gubajdulina, John Tavener), także pojawiających się w twórczości kompozytorów amerykańskich (Morton Feldman). Najprostsze formy muzyczne i skromne instrumentarium tworzą muzykę pełną pokory, a zarazem czystą i szlachetną. Dzieło Estończyka przeniknięte jest na 
w estońskiej rodzinie protestanckiej, po okresie odejścia do wiary, a następnie nawróceniu na ortodoksyjne prawosławie tworzy mistyczną muzyką do klasycznych tekstów liturgii rzymskiej. Jednym z nich jest utrzymana w stylu tintinnabuli kompozycja Cantate Domino canticum novum. Utwór wyróżnia się ciekawą notacją wykorzystującą trzy rodzaje wartości rytmicznych, co nawiązuje do notacji chorału gregoriańskiego ${ }^{41}$. Motyw czołowy, tworzący niezwykle prostą linię melodyczną, przywodzi skojarzenie z ruchem bijącego serca, wznoszący się i opadający afekt człowieczej modlitwy, modlitwy wznoszącej się ku niebu i uzdrawiającej niepostrzeżenie człowieka, który wielbi Boży majestat.

Arvo Pärt, Cantate Domino canticum novum - (utwór nr 1: 3’ 27” z CD Arvo Pärt (1935) Berliner Messe* Magnificat* Summa, wyk. Jurgen Petrenko - organ, Elora Festival Singers and Orchestra, Noel Edison, Naxos 2004).

\section{Psalm responsoryjny}

Tego utworu nie usłyszmy, bo nie można go znaleźć na żadnym nagraniu. Został zapisany w mojej pamięci i w moim sercu. Pewno każdy z nas ma taki utwór, taką pieśń, moment ciszy, który zostaje na zawsze w naszej pamięci. To było podczas mszy w mojej rodzinnej miejscowości. Ministrant, ok. 10-12-letni, śpiewał pięknym, czystym sopranem psalm, słyszałem go tylko raz, ale jego śpiew kazał mi pomyśleć o innym chłopcu, też ministrancie, z dalekiej niemieckiej wioski na pograniczu Hesji i Bawarii, o Julianie, który przez trzy lata walczył z rakiem kości i walkę tę przegrał. Pozostało jednak wspomnienie, śpiew jego rówieśnika z Polski i wiersz ${ }^{42}$, który przepisuję, by w słowach opisać muzyczne piękno tamtej chwili, piękno muzyki, która przekracza granice czasu i przestrzeni, piękno miłości, która jest większa od śmierci (por. Pnp 8, 6):

wskroś subtelną metafizyką, stając się źródłem doznań mistycznych. Laureat m. in. Wielkiej Nagrody Kulturalnej Stowarzyszenia Estońskiego w Sztokholmie (1983) oraz Nagrody im. Herdera przyznawanej przez Uniwersytet Wiedeński (2000). W albumie In Principio (ECM, 2009), zawierającym kompozycje napisane w latach 1989-2005, umieszczona została m.in. Cecilia, Vergine Romana, która została pierwszy raz zaprezentowana w Turynie z okazji igrzysk olimpijskich w 2006 roku. Obok Ennia Morricone został zaproszony w 2009 roku na spotkanie twórców kultury z papieżem Benedyktem XVI, a następnie włączony do Papieskiej Rady Kultury. Por. M. Janicka-Słysz, Pärt Arvo, [w:] Encyklopedia muzyczna PWM, t. 7, N-Pa, red. E. Dziębowska, Kraków 2002, s. 351-353.

${ }^{41}$ M. Pietrzykowska, Sakralna twórczość wokalno-instrumentalna Arvo Pärta, [w:] Sacrum i profanum $w$ muzyce wokalnej i instrumentalnej, red. M. Pietrzykowska, G. Rubin, Bydgoszcz 2010, s. 194.

42 W. Hudek, Źródta, Katowice 2012, s. 29. 


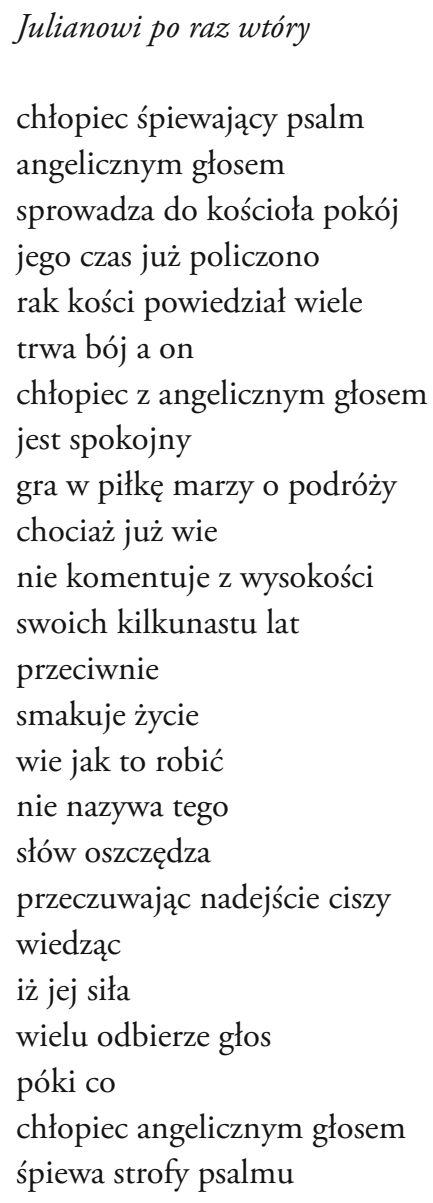

Motten 2001-2003, Kleszczówka 22 XI 2011

\section{Sortie nt. Chrystus Królem}

Zakończyła się uroczysta liturgia mszy świętej w katowickiej katedrze pod przewodnictwem Metropolity Górnośląskiego z okazji uroczystości Chrystusa Króla. Całą celebrację wieńczy uroczyste, potężne Sortie, improwizowane przez prof. Juliana Gembalskiego na motywach śpiewu Christus vincit. $\mathrm{Na}$ instrumencie znajdującym się prezbiterium katedry, tzw. małych 17-głosowych organach, prezentuje utwór o zwartej budowie, która ma wyraźne przesłanie duchowe: idźcie i budujcie królestwo dobra i pokoju, prawdy i sprawiedliwości, piękna i miłości. Ci, którzy zostają w katedrze, słyszą mimo chrystologicznych założeń śpiewu wymowę trynitarną: 
- pierwszy odcinek, część poświęcona Bogu Ojcu, ze splotów dźwięków wydobywa jasne brzmienia, jak z nicości stwarza na nowo świat;

- odcinek drugi, posługuje się ciągle motywem czołowym, tym razem opracowywanym w tonacji mollowej, z powoli zamierającą motoryką opisuje muzycznie mękę Chrystusa;

- w ostatniej części wracają początkowe tempo i dynamika, ale w nowej szacie harmonicznej, spinając cały utwór klamrą, niczym ogień Ducha Świętego, który wszystko czyni nowym i czystym.

Stąd pieśń dla Króla, stąd piękno i muzyka...

Julian Gembalski, Improwizacja nt. Chrystus Królem - (utwór nr 12: 5' 10” z CD Julian Gembalski, vol. 2, Sound of Silesian Organ, Polskie Radio Katowice 1993).

\section{Streszczenie}

„Pieśń moją śpiewam królowi” (Ps 45, 2). O kategorii muzycznego piękna w celebracji liturgicznej

Piękno muzyczne pozostaje na usługach celebracji liturgicznej. Wywiedzione z przesłanek biblijnych (por. Ps 45) i teologicznych (por. J. Ratzinger/Benedykt XVI) piękno muzyki liturgicznej prowadzi do spotkania z Bogiem, który jest najdoskonalszym Pięknem. Trzy rodzaje muzyki liturgicznej: wokalna, instrumentalna i wokalno-instrumentalna dają niezliczoną ilość możliwości docierania do P(p)iękna. Stwarzają one nie tylko bogactwo dotykania Tajemnicy, ale i bezpośredniego, intuicyjnego spotkania z Bogiem. Wśród różnych gatunków muzyki związanej z liturgią Kościoła warto odnotować te szczególnie zapisane w tradycji oraz przepisach: chorał gregoriański, polifonia palestrinowska, pieśń kościelna, muzyka organowa oraz muzyka wokalno-instrumentalna angażująca szeroki aparat wykonawczy (soliści, chór, orkiestra). Te drogi, potwierdzone historią muzyki oraz zapisane w dokumentach Kościoła, domagają się rzetelnej i estetycznej aktualizacji związanej ze znajomością „ducha liturgii” (por. Joseph Ratzinger). Ten postulat domaga się szeregu działań formacyjnych (na poziomie muzycznym, liturgicznym i duchowym). Umieszczone w artykule propozycje (psalm responsoryjny, utwór wokalno-instrumentalny na uwielbienie oraz muzyka organowa na zakończenie) stanowią przykłady tego, jak konkretnie wcielać owo piękno postulowane w dokumentach, zapisane w tekstach liturgicznych w czas i przestrzeń liturgicznej celebracji. 


\section{Summary}

I address my song to the king (cf. Ps 45, 2 ). The category of musical beauty in the liturgical celebration

The beauty of music at the service of the liturgical celebration. Derived from the biblical evidence (cf. Ps 45) and theology (cf. J. Ratzinger / Benedict XVI), the beauty of liturgical music leads to an encounter with God, who is the most perfect Beauty. Three types of liturgical music: vocal, instrumental and choral, offer countless opportunities to reach the Beauty. They create not only a richness of touching the Mystery, but direct, intuitive encounter with God. Among the various genres of music associated with the liturgy of the Church the ones that are especially worth noting are those recorded in the traditions and laws: Gregorian chant, Palestrina's polyphony, Church song, organ music and choral music with its wide range of performing arrangements (soloists, choir, and orchestra). All of these, confirmed by the history of music, and recorded in the documents of the Church, are demanding reliable and aesthetic updates in relation to the knowledge of "the spirit of the liturgy" (cf. Joseph Ratzinger). This requirement calls for a series of actions of formation (on the musical, liturgical and spiritual level). The proposals placed in the article (responsorial psalm, choral music for worship and organ music at the end) are examples of how specifically the beauty called for by the documents, written in the liturgical texts - is to be incarnated into the time and space of the liturgical celebration.

Słowa kluczowe piękno, celebracja liturgiczna, chorał gregoriański, muzyka organowa, muzyka wokalno-instrumentalna

Keywords beauty, liturgical celebration, Gregorian chant, organ music, choral music

\section{Bibliografia}

Augustyn, św., Wyznania, tłum. T. Kubiak, Kraków 1994.

Dąbek S., Twórczość mszalna kompozytorów polskich XX wieku (1900-1995), Warszawa 1996.

Dąbek S., Wokót problematyki pojęciowej oraz pewnych idei, w kontekście dziejów wielogtosowej muzyki w Polsce (do Vaticanum II), [w:] „Thesaursus Musicae Sacrae summa cura servetur et foveatur". Historia i wspótczesność muzyki liturgicznej w Polsce 100 lat od wydania Motu proprio papieża Piusa X, red. S. Dąbek, I. Pawlak, Lublin 2004, s. 106-117.

Dąbek S., Wspótczesna muzyka religijna. Uwarunkowania i aspekt duchowy, „Ethos” 7374 (2006), s. 76-86. 
Delimat W., Ksztatcenie muzyków kościelnych $w$ Polsce i jego wptyw na repertuar muzyki sakralnej, [w:] Muzyka w stużbie liturgii, red. R. Tyrała, Kraków 2005, s. 97-106.

Dunikowska B. F., Akt twórczy organisty $w$ ramach liturgii Kościoła rzymskokatolickiego w kontekście wartości, [w:] Wartości w muzyce, t. 4, Muzyka w środowisku spotecznym, red. J. Uchyła-Zroski, Katowice 2012, s. 205-218.

Gładysz J. M., Muzyka instrumentalna $w$ tradycji sanktuarium $w$ Tuchowie, „Biuletyn Stowarzyszenia Polskich Muzyków Kościelnych” 5 (2010), s. 61-65.

Hudek W., Muzyka instrumentalna w tradycji sanktuarium w Piekarach Ślaskich, „Biuletyn Stowarzyszenia Polskich Muzyków Kościelnych” 5 (2010), s. 49-60.

Hudek W., Organista i jego postuga - refleksje liturgiczno-muzyczne, [w:] W. Hudek, Stowa dźwiękiem malowane, Lublin 2005, s. 55-62.

Hudek W., Zasady doboru śpiewów mszalnych, [w:] Sacrum i profanum w muzyce wokalnej i instrumentalnej, red. M. Pietrzykowska, G. Rubin, Bydgoszcz 2010, s. 172-188.

Hudek W., Źródta, Katowice 2012, s. 29.

Jan Paweł II, List „Mosso dal vivo desiderio” ogtoszony w setna rocznice Motu proprio „Tra le Sollecitudini” o muzyce sakralnej, „Ethos” 73-74 (2006).

Janicka-Słysz M., Pärt Arvo, [w:] Encyklopedia muzyczna PWM, t. 7, N-Pa, red. E. Dziębowska, Kraków 2002, s. 351-353.

Jasiński T., Jana Pawła II myśl o sztuce i dwanaście muzycznych kontrapunktów, Lublin 2006. Ksiegga psalmów, tłumaczył z hebrajskiego C. Miłosz, Paryż 1981.

Liturgia Godzin, t. 2, Poznań 1984.

Liturgia Godzin, t. 3, Poznań 1987.

Malik E., Udziat orkiestry dętej w liturgii na przyktadzie dziatalności mtodzieżowej orkiestry dętej „Camerata” z parafii św. Rocha w Starych Budkowicach, „Biuletyn Stowarzyszenia Polskich Muzyków Kościelnych" 5 (2010), s. 31-40.

Marini P., Liturgia i piękno. Nobilis pulchritudo, tłum. W. Dzierża, Pelplin 2007.

Pasierb J. S., Stowo Boże między ludżmi, Katowice 2010, s. 175.

Pawlak I., Muzyka instrumentalna w świetle dokumentów Kościota, „Biuletyn Stowarzyszenia Polskich Muzyków Kościelnych” 5 (2010), s. 17-25.

Pawlak I., Muzyka liturgiczna po Soborze Watykańskim II w świetle dokumentów Kościota, Lublin 2001.

Pietrzykowska M., Sakralna twórczość wokalno-instrumentalna Arvo Pärta, [w:] Sacrum i profanum $w$ muzyce wokalnej i instrumentalnej, red. M. Pietrzykowska, G. Rubin, Bydgoszcz 2010, s. 190-199.

Piekarz G., Organista - zawód czy powotanie?, [w:] Cantate Domino Canticum novum. Księga pamiątkowa dedykowana Księdzu Kazimierzowi Pasionkowi, red. S. Garnczarski, Tarnów 2004, s. 293-307.

Pismo Święte Starego i Nowego Testamentu, opracował Zespół Biblistów Polskich z inicjatywy Towarzystwa Świętego Pawła, Częstochowa 2009. 
Pociej B., Sacrum w muzyce dzisiaj - problem estetyki, Lublin 1982.

Pociej B., Stadia muzycznej duchowości. Trzy wyktady, Katowice 2009.

Psatterz Dawidów w przektadzie Jana Kochanowskiego, red. B. Banaszek, Sandomierz 2000, s. 90.

Rakowski T., Muzyka instrumentalna $w$ tradycji katedry pelplinskiej, „Biuletyn Stowarzyszenia Polskich Muzyków Kościelnych” 5 (2010), s. 44-48.

Ratzinger J., Nowa pieśń dla Pana. Wiara w Chrystusa a liturgia dzisiaj, Kraków 1999.

Reginek A., Miejsce i znaczenie kościelnych zespotów śpiewaczych w liturgii po Soborze Watykańskim II, [w:] Muzyka liturgiczna w Kościele Katowickim 1925-2005, red. W. Hudek, Katowice 2005, s. 45-52.

Sobór Watykański II, Konstytucja o Świętej Liturgii, [w:] A. Filaber, Prawodawstwo muzyki kościelnej, Warszawa 2008, s. 37-42.

Szymik J., Theologia benedicta, t. 1, Katowice 2010.

Świattość świata: Papież, Kościót i znaki czasu. Benedykt XVI w rozmowie z Peterem Seewaldem, przekł. P. Napiwodzki, Kraków 2011, s. 183.

Waloszek J., Teologia muzyki. Wspótczesna myśl teologiczna o muzyce, Opole 1997.

Wit Z., Zaangażowanie świeckich w postugi muzyczne w liturgii, [w:] Muzyka liturgiczna w Kościele Katowickim 1925-2005, red. W. Hudek, Katowice 2005, s. 27-43.

Zając A., Teologiczne aspekty uczestnictwa chóru w liturgii, „Liturgia Sacra” 7 (2001) 1 (17), s. 95-108. 